perhaps because the declared luminary of the subject, Pavlov, unlike Lysenko, was long dead; perhaps because there was a greater urgency to solve the practical crisis in agriculture than to employ science instead of naked coercion in the production of the new socialist man.

Oddly, however, although Joravsky documents the debates extensively he makes no great effort to address these

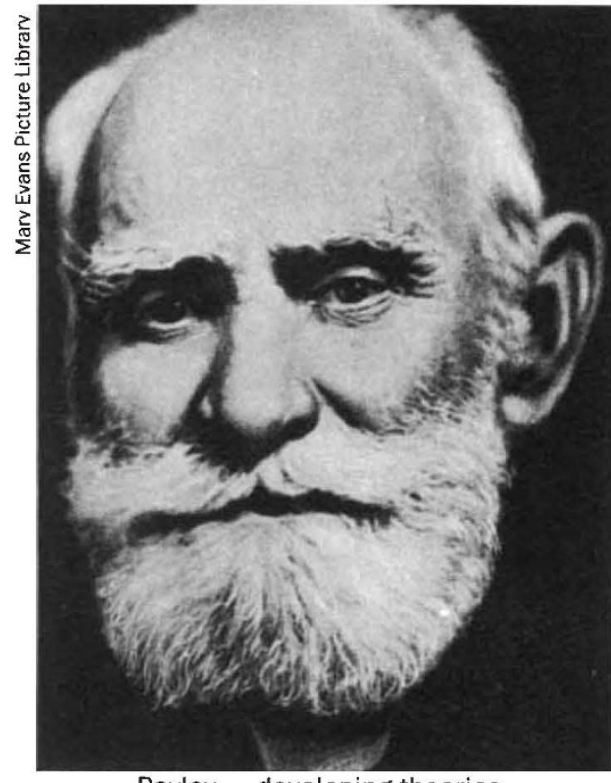

Pavlov - developing theories.

broader questions, and the omission is characteristic of a book which in the last analysis yields much less than it promises. Joravsky is not an internalist historian; he is not so much concerned with experimental findings which led Pavlov, Kornilov, Vygotsky or Luria to their theoretical positions, or with the ebb and flow of the scientific debate; rather, he is offering us a metahistory of psychology, an account of the ways in which the leading protagonists of the discipline in the 1920s and 1930s sought to locate their theories within the swirling currents of the party-led attempts to establish a Marxist orthodoxy. In effect this book is not so much a history of Russian psychology but of psychology in Russia.

The author's scholarship is formidable, and the phrenology he has created whilst denied entry into the Soviet Union or access to many key papers is impressive, despite the fact that the book has, on internal evidence, been a very long time in the making and is the weaker for it. Nonetheless, Joravsky creates the strong impression of being in the last analysis rather bored by the scientific questions which dominate the professional lives of the subjects of his history. A reader of this book who opened it knowing nothing even of Pavlov's key experiments and theories would close it being little the wiser, though he would have learned that Pavlov was a vain, opinionated and authoritarian little man whom Joravsky doesn't like very much. Indeed, Joravsky finds it diffi- cult to observe admirable qualities in almost any of his protagonists. If they don't speculate about the broader significance of their results he finds them narrow technocrats; if they do, they are shallow philosophers, or time-servers who would mould their theories to political exigencies. The treatment - or rather dismissal - of Rubinshtein, Luria and Anokhin in this way is inexcusable in however critical a history. A couple of what Joravsky would probably regard as boringly internalist histories of Russian psychology were published some years ago and do a much more useful job in this regard.

Joravsky would probably respond by saying he wasn't trying to write that sort of book at all. His elegantly worked-over prose, full of ironic asides, musing selfreflections and studied ambiguities may in some ways best be read as an unspoken historiographic debate with what has become known as the Edinburgh school in the sociology, history and philosophy of science, which seeks to reduce debates

\section{Pens and petals}

\section{Ray Desmond}

The Art of Botanical Illustration: The Classic Illustrators and Their Achlevements from 1550 to 1900 . By Lys de Bray. Christopher Helm, London: 1989. Pp. 192. £25.

THE drawing of flowers - whether for research, decoration or simply for pleasure - is the subject of an impressive literature. A distinguished pioneer in this field was Agnes Arber, whose survey of printed herbals and their woodcut illustrations, Herbals: Their Origin and Evolution (1912; 2nd edn, 1986), has become a classic. Another well-known and authoritative text is Wilfrid Blunt's The Art of Botanical Illustration (1950; 3rd edn, 1955). His Illustrated Herbal (1980), written in conjunction with Sandra Raphael, complements Arber's volume in dealing primarily with the manuscript herbal.

These are just three of many books dealing with aspects of botanical art that have appeared during the course of this century, many of them during the 1970s and 1980s. Artists such as Leonardo de Vinci, Albrecht Dürer, Jacques le Moyne, Georg Ehret, Sydney Parkinson, PierreJoseph Redouté, Mrs Delaney and Marianne North have all been the subject of monographs. Other authors have looked at flower drawing and painting from the point of view of the bibliographer and the printer, while exhibitions, museums and auction houses have each generated accounts of specific collections.

Any new book in this area has to be about fact and theory in science to a reflection of the interests - the social origins and positions - of the main characters. Joravsky's own interest, as the doyen of the history of Soviet science in the West, remains somewhat unstated. He offers himself as an outsider, neither a sympathizer with nor enemy to communism, an olympian observer and chronicler. But in practice he cannot sustain such detachment; his language constantly lets him down, as when, for all his reading of the Marxist classics, confronted with that robust concept 'working class' he routinely bowdlerizes it to 'lower class'. A real critical history of Soviet psychology, which transcends internalist-externalist boundaries, and helps us to rescue its rational kernel from both Eastern and Western ideological trappings, remains to be written. It will be worth waiting for.

Steven Rose is in the Brain and Behaviour Research Group, Department of Biology, Open University, Walton Hall, Milton Keynes MKT GAA, UK.

judged against the high standards set by some of its predecessors. Even though Lys de Bray's The Art of Botanical Illustration has no pretensions to original research, aimed as it is at a general readership, and is generously illustrated with colour plates, it is an unhappy piece of work. There are frequent signs of haste in its preparation and the text bristles with errors - misspellings, mistakes in dates of birth and death and in dates of publication - some of which are doubtless due to careless proof reading.

These slips are irritating but others are more misleading. Jacobus van Huysum was employed by Sir Robert (not Horace) Walpole; William Kilburn did not contribute any plates to the Botanical Magazine; B. Maund and E.D. Smith were connected with the Botanic Garden not the Botanical Register; J.N. Fitch lithographed plates for the Botanical Magazine but he did not succeed his uncle as artist to the journal. There is no evidence that William Kent landscaped the Prince of Wales's garden at Kew (which was much more than the 11 acres stated by Ms de Bray); Princess Augusta did not extend her property at Kew after the death of Queen Caroline; and W.T. Aiton did not resign from Kew in 1841, he merely relinquished control of the small botanical garden there. This is not an exhaustive list.

It is unfortunate that the author should have chosen The Art of Botanical Illustration as her title because it invites comparison with Wilfrid ('Wilfred' in Ms de Bray's book) Blunt's volume. Clearly, though, it poses no threat to the status of the earlier work.

Ray Desmond is at the Royal Botanic Gardens, Kew, Richmond, Surrey TW9 3AB, UK. 